\title{
From Bach to Helloween \\ 'Teutonic' stereotypes in the history of popular music and heavy metal
}

\author{
Jan-Peter Herbst
}

Throughout the centuries German popular music has caused various foreign reactions from admiration to outright rejection. Sometimes, international audiences perceived it as too 'Teutonic', other times this was exactly the reason for appeal. This article traces 'Teutonic' features in 400 years of German popular music history, seeking to identify the emergence and development of 'Teutonic' stereotypes as well as their perception inland and abroad. The metal discourse was analysed based on a corpus of nearly 200,000 pages from magazines such as the British Kerrang! and the German Metal Hammer, Rock Hard and Deaf Forever. Stereotypes such as perfectionism, precision and rigidity seem to stem from historical roots, yet their projection onto 'Teutonic metal' is over-simplified and often out of context. History suggests that German metal bands were most successful when they exaggerated Germanness. Occasionally bands became successful because their German features made them sound unique, even though they did not promote their heritage proactively. More often, though, bands that were unintentionally perceived as typically German were less appealing to a foreign audience. In the magazines, discussion of Teutonic attributes almost vanished in the 21th century. Global production practices needing to conform to international expectations of ever faster, tighter and heavier records likely made metal artists around the world adopt qualities that previously defined 'Teutonic music'. It will therefore be interesting to see if or how German stereotypes in metal music will live on.

\section{Introduction}

In 1902, the British journal The Musical Times and Singing Class Circular published an article about the premiere of Richard Strauss's one-act opera Feuersnot in Berlin. The anonymous author A.K. (1902: 808) acknowledged the huge success in Strauss's native Germany but considered the work "in many respects so very Teutonic, that it would be rash to predict its quick dissemination elsewhere". The author did not specify the Teutonic features but journalistic, polemic and academic texts from the $18^{\text {th }}$ to the $20^{\text {th }}$ century suggest that music critics, composers, conductors and performers understood characteristics of a country's music. More than sixty years after the premiere of Feuersnot (1902), Kraftwerk presented themselves as music robots, followed by metal bands such as Accept, Running Wild and Rammstein who attracted attention for stereotypical 'Teutonic' features like perfectionism, rhythmic rigidity and precision.

Previous research on 'Teutonic metal' has investigated musical characteristics based on interviews with musicians, producers and journalists (Herbst 2019,2020), and a small body of journalistic (Mader et al. 1998) and academic (Burns 2008; Kahnke 2013; Elflein 2017) literature has studied musical, historical and cultural features of German metal. Conforming to stereotypes, metal from Germany was perceived as 'clinically precise' and 'sterile', a quality often not appealing to audiences abroad (Herbst 2020). Yet, bands deliberately playing with German stereotypes, Kraftwerk (Littlejohn 2009) and Rammstein (Burns 2008), got more positive reception than authentic German bands such as Running Wild and Rage who were mocked and rejected for unintentionally coming across as 'Teutonic' (Herbst 2020).

This article traces stereotypical 'Teutonic' features in 400 years of music history, seeking to find answers to these questions:

- What are stereotypical 'Teutonic' features in popular music and how did they emerge and develop?

- How were 'Teutonic' musical characteristics discussed inland and abroad? 
- How accurate are the stereotypical perceptions of 'Teutonic metal' against their historical background?

After an introduction to the 'Teutonic label' and the history of Germany, musical practices from the baroque period to modern metal will be investigated chronologically. Sources for older popular music up to the 1980 s will be academic, the metal music discourse thereafter will rely on journalistic magazines from Germany and the UK with a total corpus of nearly 200,000 pages: 997 issues of British Kerrang! (1985-2006), 426 issues of German Metal Hammer (1984-2018), 130 issues of Rock Hard (1983-2018) and 24 issues of Deaf Forever (20142018). Unlike in the USA where the radio was crucial for the success of rock and metal artists (Gehlke 2017: 234), music magazines in Europe determined common perception (Mader et al. 1998: 108-109). Kerrang! was extremely influential in shaping public and professional opinion as an interview statement by American Laaz Rockit singer Michael Coons in 1985 demonstrates: "Kerrang! is a kind of bible of heavy metal for you in Europe, and the record companies were careful about licensing the album" (Metal Harry 1985: 21; translation). Metal Hammer and Rock Hard belong to the earliest, still active metal magazines in Germany. Deaf Forever as an offshoot of Rock Hard is less influenced by commercial interests and more critical in nature.

\section{Teutons and symbolic boundaries}

Analysing perceptions of 'Teutonic music' requires contextual historical knowledge. The term 'Teuton' goes back to the late second century BC when a north European tribe from Jutland, which today is south Denmark and north Germany, attacked the Roman Republic. Even though defeated in 102 BC, they came to be known as Furor Teutonicus, 'Teutonic Fury'. The tribe eventually disappeared but the name remained as a synonym for Germans (Kerr \& Wright 2015: 655). Over a millennium later in 1190, the term 'Teuton' appeared again with the foundation of the 'Order of Brothers of the German House of Saint Mary in Jerusalem'; in shortened form 'Teutonic Order' or 'German Order' (Innes-Parker 2013: 102). This Christian Order is active until today and changed headquarters several times to Italy, Poland, Germany and Austria.

The land that now is Germany was governed by various authorities between 800 and 1866 : the Carolingian Empire, East Francia, the Kingdom of Germany (Latin: Regnum Teutonicorum), the Holy Roman Empire and the German Confederation. In 1871, the German Empire (1871-1918) was founded. It included most of the German states, the four kingdoms Prussia, Bavaria, Saxony and Wuerttemberg as well as several duchies that are now part of Germany and France. The two German-speaking countries Switzerland and Austria did not belong to the German Empire. Prussia was the leading force and largest kingdom with lands that today belong to Poland, Russia, Lithuania, Denmark, Belgium, Switzerland and the Czech Republic. The empire was succeeded by the Weimar Republic (1918-1933). After the German Reich (1933-1945), Germany split into the Federal Republic of Germany and the German Democratic Republic by 1949 until its reunification in 1990.

This short historical overview suggests that equating the term 'Teuton' with Germany has some validity because it has been associated with different relevant authorities in this geographical region for over two millennia. However, the term should not be limited to Germany or German-speaking countries including Switzerland and Austria, as suggested by Rock Hard (Schürer 2009), given that 'Teutonic borders' have moved throughout history and included several of today's countries. Yet, since 'Teutonic territory' is generally associated with German-speaking countries, Germany in particular, this article comprehends it as such.

The following investigation will show that the term 'Teutonic' has been used within its boundaries and by outsiders. Cohen (1985), Anderson (1983), and Hobsbawm and Ranger (1983) have argued that societies are symbolically constructed by myths and invented traditions 
as an 'imaginary community' to define values and cultural practices. These can include musical heritage like instruments, forms, melodies, rhythms and performative styles. Collective identity is often also defined by 'otherness' (Elias \& Scotson 1994); hence communities outside the 'Teutonic borders' may wish to isolate themselves from Teutonic norms. Consequently, the word 'Teutonic' has sometimes been used by non-Germans in a derogatory way (Wahrig 1984), which will also be seen in journalistic writings on German metal.

German scholars have rarely studied the Germanness in popular music. One exception is the collected edition Typically German: (Self-)Views on Popular Music in our Country (Helms \& Phleps 2014; translation) resulting from a themed conference in 2013 by the German Society for Popular Music (GfPM). The authors collectively rejected the notion that much in modern music is typically German. Heesch (2014: 127) reasoned that prototypically German features could be found in Richard Wagner's operatic-cycle The Ring of the Nibelung (1876) but nowhere in recent popular music.

\section{The baroque, classical and romantic periods}

According to Lawson and Stowell's (1999) analysis of historical performance, three principal national idioms existed in baroque (ca. 1600 to 1750) music: Italian, French and German. These idioms did not only show in compositions and social contexts but also in performance styles, instrumentation and sound ideals (Lawson \& Stowell 1999: 42). The Italian style was characterised by virtuosity; a feature lasting for several centuries, even in the less improvised classical period. The French style became known for its "formal severity, refined precision and thoroughly ordered, mannered approach" that was achieved by meticulously detailed performance instructions (Lawson \& Stowell 1999: 42). The German style was less distinct, rather combining the French 'delicacy' with the Italian 'vitality' (Lawson \& Stowell 1999: 43f).

Music in the classical period (ca. 1730-1820) was becoming more international, though culture-specific features still existed in the rhythms and folk traditions, showing most prominently in dance songs, musical instrument preferences and orchestra arrangements (Lawson \& Stowell 1999: 45f). Classical scores give first hints about the stereotypical German trademark of precision. Before the invention of the metronome, figurative French and Italian time-words were being used. These verbal tempo markings were too vague for Ludwig van Beethoven (1770-1827) (Dorian 1966: 199), so he began describing tempos as accurately as possible, which for instance led to excessive specifications like "Andante con moto assai vivace quasi Allegretto ma non troppo" in his Mass in C major (Lawson \& Stowell 1999: 61). However, descriptive tempo markings were interpreted differently in various countries. The German newspaper Allgemeine musikalische Zeitung in 1809 requested that "German music must not be played in French tempos" (Brown 1999: 305). Another author criticised that allegro was played differently in France, Germany and Austria (Brown 1999: 305). Through collaboration between Beethoven and German inventor Johann Nepomuk Mälzel (1772-1838) the metronome was invented in 1815 (Dorian 1966: 194), allowing Beethoven to specify the tempo by exact markings and to normalise tempos between countries (Dorian 1966: 197). Subsequently, Beethoven became the first notable composer using metronome marks (Kolisch \& Mendel 1943: 173). Other renowned German composers, Johannes Brahms, Felix Mendelssohn and Gustav Mahler, did not see the need for a metronome, and eventually Beethoven lost interest too (Dorian 1966: 199ff; Brown 1999: 284). Still, classical music from Germany kept its image of being metronomically precise.

Tempo deviations for expressive effect were discussed passionately by 'Teutonic' composers and music critics during the classical and romantic (ca. 1780-1910) periods. Carl Philipp Emanuel Bach (1714-1788) was convinced of the artistic value of "beautiful offences against the beat" but stressed "the overall pace of the beat must be precisely maintained" (Bach 1753: i, III, §8; translation). Soloists could deviate from the ensemble tempo if they did not disrupt 
performance precision of the accompanying instruments. Friedrich Guthmann agreed: "Taken as a whole the tempo must always remain constant, even if it constantly deviates in individual places" (Brown 1999: 382). Until the end of the $18^{\text {th }}$ century it was commonly accepted that the beat should remain steady unless the score dictated a new tempo. This convention changed around 1800 when soloists increasingly disturbed the orchestra by deviating from the tempo as they pleased (Brown 1999: 382). After three decades, expressive tempo modifications using ritardando and accelerando had become the norm for soloists (Brown 1999: 384). Yet, for orchestral players it remained their duty to "keep in the most exact manner to the tempo once it has been set by the leader" (Brown 1999: 389). But not everybody agreed. Pietro Lichtenthal in 1826 criticised metronomically accurate performances to "lack magic" (Brown 1999: 390), and progressively orchestras did not only fluctuate in tempo to follow the soloist but rather modified the tempo on their own to shape the overall feel of a section (Brown 1999: 390). Opinions were clearly divided about this development. Felix Mendelssohn (1809-1847) was amongst the strongest proponents of the classical aesthetic valuing regularity of tempo (Brown 1999: 391). This strictness to tempo made him popular in the English-speaking world that saw him as successor to 'Teutonic composers' like Haydn, Mozart and Beethoven (Brown 2003: 388).

The greatest advocate of tempo modification, advising "interpretative conducting" in his writings and practice, was the artist most commonly regarded as a 'Teutonic composer', Richard Wagner (1813-1883). In his renowned book On Conducting (1869), Wagner reveals that he had used metronome markings in his early compositions but soon refrained from doing so because expressive effect could be maximised by modifying the tempo throughout a piece, movement or even section. To him, a flexible tempo supported precise articulation of all musical ideas best, which was not possible with steady time. That is why he criticised Mendelssohn's tendency towards playing pieces too fast and hasting over difficult parts. All the nuances important to Wagner could not be articulated if the tempo was not appropriate; hence a steady tempo was most detrimental to a piece. This new style of interpretation did not find unanimous agreement abroad. English music critic Henry Chorley found Wagner's conducting of a Beethoven symphony in the Philharmonic Society in London in 1855 "full of... ill measured rallentandos" (Brown 1999: 394). The English audience rather preferred the stiffer interpretation of earlier German classical music. Italian perception was similar as a quote by Giuseppe Verdi (1813-1901) indicates: "what you were just telling me about German conductors and their arbitrary treatment of tempi - that is beginning to spread rapidly in Italy too; it is almost comic to observe how many of our young conductors endeavour to change the tempo every ten bars or introduce completely new nuances into every insignificant aria or concert piece" (Brown 1999: 395). Notwithstanding dividing opinions, Wagner's conducting style influenced large parts of Europe in the second half of the $19^{\text {th }}$ century by the so-called "Germanic school of conducting" (Ardoin 1994).

Mendelssohn and Wagner represent two extreme poles in German conducting and performance styles. According to Ardoin (1994: 18), Mendelssohn's classical style was "characterized by quick, even tempos and imbued with what many people regarded as model logic and precision [...], Wagner's way was broad, hyper-romantic and embraced the idea of tempo modulation". Both artists are famous as 'Teutonic' composers and conductors (Brown 2003: 388; Heesch 2014). Mendelssohn represents a logical and precise style of music, very much akin to modern stereotypical notions of German music, matching the metronomic precision ascribed to more recent forms of German popular music. Wagner, on the contrary, not at all conforming to this aesthetic, has been cited as inspiration by 'Teutonic bands' from Germany and abroad: Grave Digger (2003), Rammstein (Reissman 2004), Laibach (2009), Klaus Schulze (1975), Apocalyptica (2013) and even American true metal band Manowar (Joe 2010). Wagner's perfectionism led to his renowned Gesamtkunstwerk wherein every aspect of music, stage and 
show is meticulously designed and aligned. This Gesamtkunstwerk influenced record producer Phil Spector's 'wall of sound' in the 1960s (Spector 2003), which metal producers adopted and developed further.

\section{Weimar Republic and Nazi Germany}

After World War I (1914-1918), the classical stereotype of rigorous, precise, rigid and temposteady music from Germany developed much more prominently, even though Wagner's disciples like Wilhelm Furtwängler (1886-1954), one of Germany's leading conductors in the early $20^{\text {th }}$ century, continued tempo-modulated interpretative conducting. Searching for a cultural identity, German musicians rediscovered "spiritually intact heroic national figures" (Hill 1994: 38) in baroque composers such as Johann Sebastian Bach (1685-1750) and Georg Friedrich Händel (1685-1759). This was accompanied by an ideology known as Neue Sachlichkeit (new objectivity) that endeavoured avoiding lush idioms of romantic music (Hill 1994: 39) in favour of a rational approach to music. Formal classical aesthetic was therefore reintroduced, and with it the steadiness in tempo. However, the new objectivity movement of the early $20^{\text {th }}$ century overstated the strict tempo, and so performances became more rigid than they originally were in the classical period (Hill 1994: 42). The movement was inspired by Mendelssohn's approach of "absolutely symmetrical measures, designed for absolutely symmetrical playing" (Hill 1994: 49), which soon led to clean and sterile performances that Eugen d'Albert criticised in 1927: "In former times one places the most value on individuality and on spiritual depth of playing, today these things are of less and less concern. The emphasis [today] is on an immaculate, pearly style and a clean, smooth technique" (Hill 1994: 50). In retrospect, the new objectivity distorted public understanding of German classical music and contributed to its perception as precise but mechanical.

At the same time when classical music became increasingly sterile, a very different musical culture slowly found its way into Germany: American jazz. Other Central European countries like France or Britain imported jazz approximately five years earlier than Germany did because of the war. It was not before 1924 that citizens in metropoles like Berlin experienced live shows by foreign ensembles and inauthentic German copies (Kater 1988: 145). Jazz got a moderate boost when Deutsche Grammophon introduced its jazz sub-label Brunswick in 1926, and by 1930, jazz-inspired dance music became more common on the radio. However, little authentic American 'hot jazz' was broadcasted, rather 'lighter' versions to the tastes of the German audience (Kater 1988: 146). Rhythmically, this Europeanised form of jazz differed significantly from authentic American 'hot jazz':

\footnotetext{
"Where the accents of European melodies tend to fall either on the thesis or the arsis of the rhythmic foot, the main accents of African melodies - especially those of 'hot' music - fall between the down- and the up-beats. The effect thus produced is that of temporal displacement of the melodic phrase, in its relationships to the percussion phrase, to the extent of a half beat." (Waterman 1948: 25)
}

German musicians hardly managed to perform the rhythmic qualities of jazz convincingly. Whereas jazz in America worked well with social dance forms like ragtime, shimmy, Charleston and foxtrot, German ensembles kept traditional European forms like waltz, march and paso doble (a Spanish military march), which did not fit together. Consequently, "their capacity for 'swinging', that indefinable ingredient in true jazz, was curtailed" (Kater 1988: 152). Most jazz performed by German ensembles was thus perceived as unintentionally comical and disliked by music critics (Kater 1988: 151).

Only five years after jazz music's emergence in Germany, it already started to decline due to political changes. For ideological national-socialist reasons jazz was disdained and later banned as "degenerated music", owed to some degree to its rhythmic qualities. In 1930, the 
music magazine Melos wrote: "The foundations of jazz are the syncopations and rhythmic accents of the negroes; its contemporary form is the work of the Jews, mostly Tin Pan Alley Jews from New York. Jazz is negro music, perceived through the eyes of these Jews" (Wicke 1997; translation). Similarly, a Hitler youth leader in 1936 expressed: "The Nigger has a very pronounced feeling for rhythm, and his 'art' was perhaps indigenous but nevertheless offensive to our sentiments" (Kater 1989: 15). The musical qualities yet were partly an excuse to reject jazz music, the true reason was racist Nazi ideology. Alleged scientific research was used in an attempt to prove the inferiority of the black race, and consequently the music needed to be degraded as well. To strengthen the argument, direct links were drawn between jazz and Jews to conveniently connect two enemy images whilst also scorning American popular culture (Kater 1988: 154f; Wicke 1997). Dr Wilhelm Frick, Minister of the Interior in the Thuringian government, prohibited jazz music in his state in 1930 (Kater 1988: 157). In 1935, jazz was finally banned on all radio broadcast in Germany by the Reichskulturkammer, the Imperial Chamber of Culture (Wicke 1997). This rule did not eliminate all jazz because subversive strategies still enabled some unauthorised performances and broadcasts (Kater 1989: 13), yet little American popular music was available in Germany between 1930 and 1945.

\section{Post-WWII}

The post-war period in Germany was marked by a search for the country's identity. Back then mainly Schlager was produced, a form of escapist German popular music with lyrics about everyday life, holiday and travel (Ritzel 1998). In the 1950s, rock'n'roll influenced the youth generation, but apart from a few inauthentic copies like Peter Kraus, this style of music was rather consumed than produced (Adelt 2016: 6, 12). The same was true for beat imported from Britain in the 1960s (Klüsener 1989: 134), which provoked German copies like the Rattles and the Lords. Until the late 1960s, German musicians rejected any forms of Germanness (Stubbs 2010: 5). This changed with the emergence of 'krautrock' (1968-1974), a movement intended to defy the gradual Americanisation of West Germany by creating an original form of popular music, and with it a renewed German identity. British DJ John Peel labelled the music as 'krautrock', a term used synonymously with 'Teutonic rock' (Adelt 2016: 11). One of the first krautrock artists that explored new forms of rock, neither American nor British, were Can. Their keyboardist Irmin Schmidt in an interview explained:

\footnotetext{
"The point was that here in Germany the dominant belief was that one has to play like the English or the Americans in order to be taken seriously as a rock-, pop-, or beat-musician. When we started out, the critics said: they cannot play properly. We answered: that's right! We also don't want to play like the English or the Americans." (Schmidt in Schiller 2014: 620)
}

Can had a special relationship with technology and created the blueprint of the "man-machine" hybrid (Adelt 2016: 23). Soon after, Kraftwerk, an art project by students of classical music, Ralf Hütter and Florian Schneider, perfected this hybrid approach, making a robotic sound their trademark and linking it with an exaggeratedly stereotypical German image. Provocative statements by Hütter reflect this: "We create out of the German language [...], which is very mechanical, we use as the basic structure for our music" (Bangs 1975) and "We have a Teutonic rhythm, really Germanic" (Barr 1998: 142). The music and the band's staged performances were perceived as "very tidy and technically precise with their machines" (Bussy 1993: 82), "typically German [...]: distanced, cold, perfectionist and highly effective" (Dallach 2003: 154) and "precise, efficient" (Petridis 2003: 2), thereby shaping the foreign conception of how popular music from Germany sounds like. Apart from this mechanical rhythmic quality, Kraftwerk adopted Wagner's Gesamtkunstwerk, which they first used on their record Autobahn (1974). This album strongly influenced the Neue Deutsche Welle, a German version of new wave between 1979 and 1983, which continued Kraftwerk's robotic style and cold synthesiser sounds. Once more, it was stereotypically 'Teutonic' bands like Einstürzende Neubauten and 
Die Krupps that became internationally successful, not acts refusing to emphasise their German heritage (Adelt 2016: 165f). The new German wave was significant for rock and metal because it established the infrastructure for the metal boom in Germany in the mid-1980s by nurturing independent labels, distributors, studios and concert promoters (Klüsener 1989: 135). Curiously enough, whilst most bands of the krautrock movement wished to create a German identity marked by transnationality (Adelt 2016), Kraftwerk's international success, based on exaggerated Germanness (Littlejohn 2009), achieved exactly the opposite.

\section{Early Teutonic metal}

Early British and US-American metal had little impact on German rock music. Bands important for German metal started out as krautrock artists or bands signed by krautrock record label Brain: the Scorpions, Accept and Fargo, who later became Victory (Mader et al. 1998: 7). Since foreign records were not widely available, bands took considerable note of heavy metal abroad only in the final years of the New Wave of British Heavy Metal (1975-1983) (Gehlke 2017: 10). Hence mainly older German rock bands influenced the emerging domestic metal bands (Herbst 2019). Although the Scorpions were highly influential, it was Accept's albums in the early 1980s defining a 'Teutonic' style of metal. Singer Udo Dirkschneider recalled their 1981 record Breaker revolutionising German metal:

\footnotetext{
"There was something magical, somehow a new style was created, that happens rarely enough but all of a sudden it happened! [...] If you talk to different musicians today - 'Breaker' has influenced everyone. [...] People said to themselves: 'There's a German band, they actually do something totally untypical and they are successful!' From that point on we had a certain pioneering role." (Mader et al. 1998: 29; translation)
}

Accept's subsequent album Restless and Wild (1982) contained a track that should influence many German metal bands to come: "Fast as a Shark". Singer Hansi Kürsch of Blind Guardian (since 1987) stated "You couldn't imagine there could be a song that was faster", and Kai Hansen confirmed the impact the song's guitar riff had on his music with Helloween (since 1984) and Gamma Ray (since 1989) (Stratmann 2015: 16). Abroad, this record was also regarded as innovative. Kerrang! classed Accept as "German speed metal pioneers" and "originators within the genre" (Sheils 1998: 45), and ranked the album as the world's sixth important pre-2000 metal record for being "proto-thrash" (Alexander 1999: 20). Comparing "Fast as a Shark" (1982) with the 'proto-speed metal' song "Speed King" (1970) by Deep Purple, Accept's take on the genre was faster with $280 \mathrm{bpm}$ compared to Purple's $200 \mathrm{bpm}$, a tempo they only reached in some parts of the song. The song was released one year ahead of the debuts of Metallica (Kill Em All, 1983) and Slayer (Show No Mercy, 1983) and was competitive regarding speed.

Accept's 'German way' of playing metal was not limited to fast tempos, it involved utmost performance precision too, coinciding with stereotypes. This feature influenced many bands from the German-speaking culture (Glas 1997: 62). For example, Tom Gabriel Warrior, singer of the Swiss bands Hellhammer (1981-1984) and Celtic Frost (1984-2008), revealed having been impressed by Accept's "precision" and "clinical way of playing" in the early 1980s (Warrior 2016: 25). Even American musicians admired this performance style, as Night Demon in an interview revealed: "German bands had this precision [...]. Accept or the Scorpions were so tight in their playing, that was the exact opposite of Motörhead or the early Priest" (Kohsiek 2018: 37; translation). At the beginning of German metal, precision was commonly considered a good trademark, "If musical precision is akin to logic then Accept can rival even the most sophisticated of computer technology" (Kerrang! 1986). In the 1980s to the early "90s the British press was generally in favour of German bands as an alternative to US-American metal. Accept's accordance with stereotypes appealed to foreign audiences, making them more successful in the UK, USA and Scandinavia than in Germany (Rinne 1984: 29). Kerrang! thus 
endorsed them: "The material for the main part is [...] very Germanik - by that I mean marching riffs played intensely!" (Russell 1991: 54). However, the positive tone in British journalistic media was not to last and became increasingly prejudiced and sometimes even racist as a review of Accept's album Objection Overruled (1993) exemplarily demonstrates: "Most of the songs have a mid-tempo AC/DC feel, although Accept never really groove like AC/DC. Everything Accept do is so clinical and cartoonishly Aryan" (Van der Kirkhoff 1993: 21). From the early '90s, Accept's popularity declined in both the UK and USA while it increased in Germany.

Record labels like Noise and Steamhammer made imports of British and American bands affordable from the mid-1980s (Gehlke 2017). Listening to Judas Priest, Iron Maiden, Metallica and Slayer influenced German bands (Herbst 2019, 2021), but foreign journalistic discourse still focused on the features they perceived as typically German as per Accept's formula: precision and speed. There are countless examples as for instance Grave Digger (since 1980), who were regarded as "Accept on speed" (Russel 1986a: 9), and Rage (since 1984) who, inspired by Accept, were seen as "yet another klassy Speed Metal band from dear old Krautsville" (Russell 1986c: 16). The most well-regarded German speed metal band of the mid to late 1980s was Helloween. Their album Walls of Jericho (1985) significantly contributed to the growing European metal scene and the power metal genre (Weinstein 2011: 40) that back then was still known as 'speed metal'. Metallica's drummer Lars Ulrich expressed, "Christ, this is like Iron Maiden at a million miles an hour!", and Kerrang!'s Xavier Russell declared "Helloween have twice the power and energy of Maiden" (Russell 1986b: 10). Studying German and British magazines of that time suggests that fast playing when matching German stereotypes was celebrated internationally, whilst the German press criticised the quest for speed of numerous German bands, and not even Helloween themselves wished being reduced to fast playing (Helbic 1985). Notwithstanding efforts to avoid such a one-sided image, it was Helloween's release Keeper of the Seven Keys Pt. I (1987) that defined the sound of 'Teutonic metal' as speed metal for generations to come: "screaming guitars, machine gun drums and pitch-perfect vocals" (Beebee 1998a: 45). Apart from speed, authenticity to their German musical heritage impressed the British press:

\footnotetext{
"I'm prepared to [...] hail Helloween as true messiahs. Kings of a new epoch, fresh, vital and almost without peer. In my opinion this is the most remarkable opus since Def Leppard's 'Pyromania' halfa-decade ago! [...] if I had to choose one band that the Germanic quintet have emulated over-aboveand-beyond even this illustrious trio then [...] it has to be Queen. There is an air of déjà vu about the pin sharp, astronomical vocal harmonies, the classical influences (Brahms, Chopin, Wagner), the absolute delectation of genuinely hummable tunes all encased in dynamic rock chord changes and amplified, acceptable violence that brings home the early days of Mercury's Magnificents. [...] Given just how advanced and epochal (not to mention individual) this release is, it's difficult to establish any criteria for it, but certainly things must be stated. The guitar interplay between Kai Hansen and Michael Weikath is quite astonishing, each playing at a surreptitious speed overdriven with suitably stylised effects yet neither losing track of the desired tonefulness. I can't really compare their bounding performance to any rock guitarists (although Michael Schenker does spring to mind); rather it brings forth a vision of gifted classical musicians, from Paganini to Menuhin and Du Pre to Segovia. They reach a peak of mountainous activity on the epic 'Hellowe'en' [...], delivering a dual attack that packs both sonic salvos and whirling orgiastic frenzy, at one point even (admirably) lifting a section from Brahms' 'Hungarian Dances'. [...] Layered lovingly on top of this axe-iomatic axis are the astonishing vocals of new boy Michael Kiske [...]. And Marcus Grosskopf (bass)/Ingo Schwichtenberg (drums) play their part in fashioned, polished style. [...] it's one of Heavy Metal's all-time masterpieces.” (Dome 1987a: 15)
}

"Helloween, though, are very much in the tradition of the classic Germanic hard rock brigands, from the Scorpions to Accept. They have a tuneful countenance, a respect for the operatic past of their country's musical heritage and a firm grasp of modern studio techniques, all combined in a 
unique fashion and doused in a production that amplified their strengths and turned any weaknesses on their head, before turfing "em out of the final mix." (Dome 1987b: 16)

The two reviews praise the 'Teutonic' musical heritage with references to 'classical' composers like romantic Brahms and Wagner; a trend also present in other reviews (Russell 1987a: 30). Some German musicians were indeed strongly linked to their country's musical past as Accept vocalist Udo Dirkschneider confirmed: "A lot of German musicians use classical music as an influence. We're much closer to the classics. America is much closer to the blues. It's wrong for a German band to be like an American band. It's best to play and develop your own styles at all times" (Watts 1989: 38). Their guitarist Wolf Hoffmann in another interview elucidated that the strong influence classical music had on him was less a deliberate decision but resulted naturally from his musical socialisation (Poponina 2018). However, taken as a whole, it is unlikely that German metal musicians were influenced by classical music more than their fellow musicians from other parts of Europe who also had a respective musical heritage.

Helloween were celebrated for their fast and precise performances and links to their country's musical heritage, whereas other bands with similar features were not that lucky as two examples suggest.

\footnotetext{
"Running Wild meant about as much to me prior to this jaunt as they probably still do to you precisely nothing! Six albums in as many years ain't done nothin' to switch the UK on to 'em, but here in Germany it's a whole different ball game! There are 1500 odd punters here, many of 'em with Running Wild T-shirts on, digging the shit out of this band. From the minute that vocalist/guitarist Rock'N'Rolf, guitarist Majk Moti, bassist Jens Becker and drummer York [sic!] Michael take to the stage, the kids are eating out of their hands. It ain't hard to see why. Running Wild are so German it's unbelievable! Their music is precise, clinical and very heavy. The stuff that armies march to. Enjoyment in a regimented, serious manner. Bombastic? Wagnerian? You betcha! [...] I think maybe you've just got to feel this music in the blood to really get off on it." (Johnson 1990: 51)

"Look out, the Germans [Sargant Fury] are here. Well, four Germans and one ex-pat Geordie, to be precise. Germany appreciates precision. German hard rock is regimented, clinical and exact. As a result of that, it isn't usually very good." (Watts 1992: 21)
}

Then again, bands were celebrated exactly for their Germanness. Die Krupps (since 1980) were praised for the singer's vocals, very much akin to Kraftwerk: “Jürgen Engler's Germanic vocals play a great part in this: he's hardly a melodically masterful singer [... but] has a great, semirobotic tone" (Arnopp 1992: 18). Even more successful were Rammstein (since 1994) who played their own version of metal they referred to as Tanzmetall (dance metal). This style, framed as industrial as another reference to Germany, makes frequent use of a 'four to the floor' beat, ridiculing common practice of German folk and popular music audiences to clap on all four beats, which contrasts the emphasised backbeat of American-derived pop music. Although foreign audiences in the UK were not easy to convince - "Worryingly stern-faced industrial noise that is so Teutonic it [... is for] krautophiles and comedy fans only" (Kerrang! 1996, p. 45) - Rammstein's exaggerated Germanness eventually became their main appeal abroad: "harsh, stentorian, militaristic and impenetrable" (Everley 2001: 44), "undoubtedly the most important rock band to ever have come out of Germany. [...] classically Teutonic rhythms" (Myers 2001: 40). As generally acknowledged, Rammstein took inspiration from Kraftwerk and the Slovenian avant-garde ensemble Laibach, yet with precisely staged choreography, the singer's military tunic and their rhythmic clichés they highly resembled Accept. For example, the marching footsteps on Rammstein's "Links 2, 3, 4" (2001) were inspired by Accept's international hit "Balls to the Wall" from 1983. Such stereotypical music was appealing to a foreign audience: "classically Teutonic; all metronomic rhythms, guttural vocals and, in the case of 'Links...' [...] the sound of a thousand marching footsteps. Predictable, certainly, 
but as devastatingly effective as a Volkswagen up the arsch" (Everley 2001: 44). Rammstein made no secret of their exaggerated and inauthentic artistic concept.

\begin{abstract}
“Kruspe: This was a project where we tried to do a 'German' style of music. By this I mean a really straightforward and direct sound, maybe even a little too 'stiff' rhythmically, without a lot of looseness. That's very much a part of German culture, but we can also laugh at ourselves and our culture.

Schneider: We're even considered a little too over-the-top in Germany. We come off as more German than most Germans." (Sindell 2001: 34)
\end{abstract}

Likely owed to their inauthenticity, Rammstein are more successful abroad (Kahnke 2013: 185) than in their home country where their music is rarely played on television and radio since the band's overemphasised Germanness is commonly perceived as disconcerting (Albrecht 2000: 38).

'Speed metal', one of the harder forms of metal in the 1980s, eventually split into power metal and thrash metal. Apart from Rammstein, all bands discussed so far classify as heavy or power metal. Interestingly, renowned German thrash bands, also described as 'Teutonic Four' (Kreator, Sodom, Destruction, Tankard) in reference to the big four American bands Metallica, Slayer, Megadeth and Anthrax, were rarely subject to German stereotypes in British media. Kreator were labelled "ultimate death/hate/speed metal" (Russell 1987b: 19), Sodom "Real Metal" (Kerrang! 1987: 26) and Destruction "Another German Frash band" (Harry Headbanger 1986: 18). British media perceived German thrash favourably in the late 1980s. One possible reason the Germanness of thrash bands was not highlighted in reviews is the genre's roots in punk music. Whilst German thrash bands were just as fast as the likes of Accept and Helloween, they were far less precise (Mader et al. 1998: 9). Dilettante and sloppy playing in their formative period hardly allowed foreign media to present them as characteristically 'Teutonic'.

\title{
Metal in the $21^{\text {th }}$ century
}

In journalistic media, the discussion of Teutonic attributes almost vanished since the turn of the millennium, apart from occasional mockery by British trend magazines like Kerrang! which since the mid-1990s hardly appreciated tradition-conscious metal from mainland Europe (Beebee 1998b: 46). Although German media initially rejected the label 'Teutonic' from the British press (Herbst 2019), it was eventually adopted and is still used when writing about traditional metal bands like Accept, Grave Digger and Axel Rudi Pell. One possible reason for the declining use of the label and its associations is past and ongoing changes in production practice. As empirical studies have shown, temporal variations and rhythmic idioms in the micro-time domain are an unconscious part of musical dialects (Johansson 2010). However, technological advancements impacted on such performative features. Multi-tracking introduced in 1955 progressively affected performances by allowing to combine different takes of an ensemble performance (Zagorski-Thomas 2010: 201). When in the 1980s MIDI and drum machines emerged, metal music was not immediately affected since producers commonly kept recording acoustic drum kits. Yet the quick dissemination of drum computers in many popular music genres altered views about features of good drum playing, and time-consistency was increasingly expected (Zagorski-Thomas 2010: 205f). A significant milestone in metal music marked digital production that became common in 1990 and enabled more drastic editing; a main motivation for metal producers to move to the digital domain (Thomas 2015: 196). With the release of Pro Tools 5.1 in 2000, the metal aesthetic changed slowly but fundamentally; the 'Beat Detective' was introduced, a function facilitating aligning audio recordings to a grid ('quantisation') by separating, moving and crossfading regions with only few to no artefacts (Thornton 2018).

In this transitional phase from analogue to digital between the mid-1990s and mid-2000s, national production standards in metal production still varied considerably. Charlie Bauerfeind, 
one of the most occupied 'Teutonic' producers back then, was amongst the first to start working digitally in 1993 with a Pro Tools system that allowed editing four tracks simultaneously; an option he used to achieve the ultra-precise performances German Running Wild were looking for on their Black Hand Inn (1994) album (Herbst 2021). This production relied on drum triggering, an approach Running Wild practised since their 1987 album Under Jolly Roger (Mühlmann 2002: 45). Their quest for preciseness did not only involve exact drum performances aligned to the grid, it also extended to other instruments. For best synchronisation and avoiding micro-deviations in timing, only one of the two guitarists played the four guitar tracks; a practice the band started on their 1991 album Blazon Stone (Mühlmann 2018: 39). Moreover, band leader Rolf Kasparek recorded each of the four guitar tracks listening only to the drums. Afterwards he checked all takes against one reference track to ensure utmost precision (Herbst 2021). Since their inception Running Wild divided the German metal scene (Bittner 2009) but replacing their drummer for a drum computer - listed in the liner notes as a musician named 'Angelo Sasso' - was going too far for most of the German community (Kühnemund 2002; Mühlmann 2018). The same happened when former Accept singer Udo Dirkschneider started using drum computers on his solo albums for which he was criticised heavily (Schleutermann 2011). Studying German metal journalism indicates that whilst many German (mainly power metal) bands and their producers were tempted using new technological means to improve performance precision beyond what could naturally be performed, most of the general metal audience valued authentic performances and thus were wary of digital trickery.

In contrast to clinical productions common in Germany, sometimes perceived as 'overproduced', many metal artists abroad much longer resisted temptations that digital production technology offered. Some musicians like Rob Flynn even refused recording to a click track, "No way, for Machine Head we're totally against the use of click... they would kill all the feel and energy. We've only ever used a click track once on all our albums, and that was at the start of the track 'Violate' off The More Things Change [1997]", and producer Matt Hyde illuminated that "When I did Slayer's God Hates Us All [2001], there were some count-offs, but there's no tempo maps or click tracks. So there's these ramps where it speeds up and slows down, but that's what the music needed" (Mynett 2017: 32f). This philosophy stood in stark contrast to German metal production practice that rarely refrained from click tracks and hardly recorded live (Herbst 2021).

In the last 15 to 20 years, however, there is reason to believe that changing expectations by musicians, audiences and the industry caused international production conventions to gradually adopt the German approach. Producer Oz Craggs explained,

\footnotetext{
"I think the expectation of the listener on heavy music is an expectation of clinical precision now. I think if you were to do a certain type of heavy band and do not include the editing of tightness maybe people would feel cheated, feel like it's not tight. The technology has made the performance element transcend what was acceptable, now it has become unacceptable in some ways." (Thomas 2015: 194)
}

As Williams (2015: 44) in his analysis of changes in metal productions from 1990 to 2013 pointed out, drum sounds have become over-processed and inauthentic, are drastically edited and quantised, and the natural drums are either sample-reinforced or even replaced. Drastic use of samples yet "sterilizes a drum performance's raw energy and natural intensity. Consequently, some modern metal productions have such unnatural drum sounds they could easily be mistaken for having been programmed, with the resulting 'imitation' drum performance contributing to a 'fake' sounding production" (Mynett 2017: 35). Sometimes individual drum instruments are recorded separately, other times the drum performances are a hybrid of natural playing and MIDI programming (Mynett 2017: 79). These approaches are not limited to achieving a perfect steady tempo ('quantisation') but extend to micro-editing, allowing to op- 
timise alignment of the drum kit's instruments and synchronisation with other ensemble instruments. Although such methodologies improve performance precision and tightness, they risk introducing a mechanical sound (Mynett 2017: 106f). Global production practices assimilating the German approach ultimately made metronomically precise 'Teutonic metal' less distinct in the $21^{\text {st }}$ century. Therefore, culture-specific characteristics in metal music have gradually decreased in the quest for greater heaviness (Berger \& Fales 2005), which required ever-faster performances, tighter ensemble synchronisation and 'fat' yet controlled sounds, all of which result from sophisticated recording and production methodologies that go beyond what is possible in natural performances (Thomas 2015; Mynett 2017). From a production viewpoint, this international quest for heaviness standardised practices that proved to be most effective.

\title{
Teutonic metal revisited
}

The previous discussion demonstrated that the public discourse acknowledges a 'Teutonic' metal sound. Rock Hard recently published a special on metal from Germany, which includes an interview with ex-Helloween and Gamma Ray guitarist and singer Kai Hansen. He explained the sound of German metal:

\footnotetext{
“That it doesn't sound American or British, but German. There may be a bit of moustache, marching music, sauerkraut and operetta in it. We have that in us, you can't deny it. No American or Englishman can do that. 'Breaker' by Accept and Judas Priest's 'British Steel' are albums on the same heaviness level and sound beautifully metallic but Accept are typically German. I can't explain it better than that." (Stratmann 2015: 17; translation)
}

Heaven Shall Burn guitarist Maik Weichert, writing an article in the same Rock Hard issue, had similar problems defining the German metal sound:

\begin{abstract}
"Is there such a thing as German metal at all? And if so: What is that at all? A scene? [...] German metal is more of a national-regional quality seal from a global perspective, just like German engineering and Scandinavian design are. Only: What do you have to do to be German metal? What are the trademarks and unique selling points? Hardly any German metal band sings in German [...]. Then there are still two possibilities: Either, what would be impressive, German metal actually carries something with it that makes it musically unique, or, what would be disappointing, it's just a collection of sounds that only the country of production has in common. [...] So is German metal a style? In some cases not really, is it? But it can't be just the origin either, after all you recognise immediately when for example Hammerfall pay homage to the holy Accept. Is there such a thing as a self-image, a sense of tradition? The eternal luck that Gamma Ray will always sound like Gamma Ray and Running Wild will always sound like Running Wild? Reaction instead of innovation? Many people see this as the great strength of German metal. Who wants an experimental Grave Digger record or vocal innovations by Udo Dirkschneider? Exactly. And this is exactly where we are exploring a very important aspect. The common German metalhead is strictly conservative, almost reactionary. That's not meant to be negative at all. The German metal fan represents the shepherd dog of the metal world. Loyal, if everything is as usual, and hellishly aggressive if something is too unusual or if you want to conceal a lack of quality with cheap tricks. But this is exactly what creates an environment that promotes perfection rather than innovation." (Weichert 2015: 14; translation)
\end{abstract}

Both musicians are convinced of an existing German style of metal but have difficulties in defining it clearly as the quotes demonstrate. Weichert's reflection of German metal being perfectionistic and tradition-conscious rather than innovative accords with cultural stereotypes the previous analysis of journalistic texts suggested: Teutonic metal is bombastic, fast, regimented, "precise, clinical and very heavy" (Johnson 1990: 51). It is supposed to be true to the country's musical heritage; an expectation that relates to classical and romantic composers like Beethoven and Wagner, a common but often superficial reference with little understanding of what this means musically. Nonetheless, conforming to these national expectations was and 
still is highly appealing internationally as evidenced by artists like Rammstein. The band had this answer for the success of the 'Teutonic sound' in the USA:

\begin{abstract}
"If someone writes 'Teutonic', then he probably means 'German', maybe also 'too German'. In principle they are right. 'To be German' is a bit brute. Germans are not so filigree. As far as the secret of our success in America is concerned, I don't know. Is it a danger that we come across as too German abroad? I noticed that our foreign fans are happy that we are German. I know that in America Hitler is not seen as so bad. But we are too close here to allow ourselves to think like that. But actually there is always this reaction abroad: 'Finally something good from Germany. Nothing has come since Kraftwerk! “" (Großer 2001: 26; translation)
\end{abstract}

Selling out Germanness seems to work; it did so for Kraftwerk and also for Accept who in the early 1980s had a militaristic image, contrasting most American bands that sang about and lived a rock'n'roll lifestyle. Clever producers such as British Andy Sneap who produced all four comeback albums of Accept since 2010 comprehend this. Since emulating American bands did not bring success (Kühnemund 2014: 39; Herbst 2020), he persuaded Accept to return to their German image. This strategy of Germanness worked and Accept's latest four records entered many important American and European charts.

\title{
Conclusion
}

Throughout the centuries German popular music caused various foreign reactions from admiration to outright rejection. Carl Maria von Weber's Freischütz (1821) was perceived as "a typical product of the Teutonic romantic movement [... which] leaves a modern Anglo-Saxon audience, alas! Cold" (Williams 1932: 415) and Richard Strauss's Feuersnot (1902) was too 'Teutonic' (A.K. 1902: 808), a fate that many German metal bands shared in the 1980s and '90s.

The historical investigation has traced the emergence and development of German stereotypes in music. Whilst during the baroque period 'Teutonic' music was merely a mixture of French and Italian styles, the classical period made German music more distinct. The performances became more even, precise and logical. Even though this aesthetic was interrupted by the romantic movement that added Wagner's perfectionism, the new objectivity after World War I reintroduced the classical aesthetic and made performances stricter than ever before. African-American groove music influenced German culture relatively little for its prohibition during the German Reich's authority, and American rock'n'roll and British beat were rather consumed than produced. Krautrock wished to overcome the stigmatised German identity, but Kraftwerk's success overshadowed this intention, showing artists how exaggerated Germanness could be harnessed commercially, which again shaped Germany's musical image abroad. Some of the stereotypes related to perfectionism, precision and rigidity seem to stem from historical roots, yet lively discussions between composers and modifications of traditions throughout history suggests that this common perception is over-simplified; only some musical features were selected, altered and usually ascribed out of context. Referring to Cohen (1985), Anderson (1983), and Hobsbawm and Ranger (1983), traditions have been created and modified from the inside and outside for various reasons. Stereotypes of classical music were projected onto German metal; several artists did so themselves as well as foreign media, be it for marketing purposes, pure journalistic jargon or as excuses to dismiss the music.

The media analysis suggests that German metal bands were generally most successful when they stressed their heritage and emphasised Germanness until it became most obvious. There were also bands like Helloween who did not proactively promote their heritage but still became successful because their German features made them sound unique. More often, though, the opposite happened; bands unintentionally perceived as typically German were less appealing to a foreign audience. Curiously enough, neither musicians nor music critics seem 
capable of defining what is typically 'Teutonic' about German metal music apart from stereotypes that keep getting repeated. This is presumably due to the centuries-old mockery that still lives on for the sake of tradition. However, global production practices conforming to international expectations of faster and heavier records made metal artists around the world adopt qualities that previously defined 'Teutonic music'. It will therefore be interesting to see if or how German stereotypes in metal music will live on. The dwindling use of the 'Teutonic' label suggests it will eventually cease to exist.

\section{References}

A.K. (1902), 'Richard Strauss's 'Feuersnot' in Berlin', The Musical Times and Singing Class Circular, Vol. 43, No. 718, pp. 808-809.

Accept (1981), Breaker, Brain 0060.390.

Accept (1982), Restless and Wild, Brain 0060.513.

Accept (1982), 'Fast as a Shark', on Restless and Wild, Brain 0060.513.

Accept (1983), Objection Overruled, RCA 74321124662.

Adelt, U. (2016), Krautrock. German Music in the Seventies, Ann Arbor: University of Michigan Press.

Albrecht, F. (2000), 'Rammstein. Trampolinspringen mit den Kellys', Rock Hard, 11/2000, pp. 38-39.

Alexander, P. (1999), ‘200 for 2000: Essential Albums', Kerrang!, 779, pp. 16-36.

Anderson, B. (1983), Imagined Communities, London: Verso.

Apocalyptica (2013), 'Wagner Reloaded - Live in Leipzig', BMG 538011441.

Ardoin, J. (1994), The Furtwängler Record, Portland: Amadeus Press.

Arnopp, J. (1992), 'Krupps - I', Kerrang!, 418, p. 18.

Baach, C. P. E. (1753), Versuch über die wahre Art das Clavier zu spielen, Berlin: C. F. Henning.

Bangs, L. (1975), 'Legendary Rock Critic Lester Bangs' 1975 Interview with Kraftwerk', BigShot, https://newsflash.bigshotmag.com/features/26854; accessed 14 June 2019.

Barr, T. (1998), Kraftwerk: From Düsseldorf to the Future (with Love), London: Ebury Press.

Beebee, S. (1998a), 'Helloween - Better Than Raw', Kerrang!, 695, p. 45.

Beeblee, S. (1998b), 'Pink Cream 69 - Electrified', Kerrang!, 717, p. 46.

Berger, H. M. and Fales, C. (2005). "'Heaviness" in the Perception of Heavy Metal Guitar Timbres. The Match of Perceptual and Acoustic Features over Time', in P. D. Greene and T. Porcello (eds), Wired for sound. Engineering and technologies in sonic cultures, Middletown: Wesleyan University Press, pp. 181-197.

Bittner, R. (2009), 'Running Wild', Rock Hard, 7/2009, pp. 74-75.

Brown, C. (1999), Classical \& Romantic Performing Practice 1750-1900, Oxford: Oxford University Press.

Brown, C. (2003), A Portrait of Mendelssohn, Yale: Yale University Press.

Burns, R. (2008), 'German Symbolism in Rock Music. National Signification in the Imagery and Songs of Rammstein', Popular Music, 27:3, pp. 457-472. 
Bussy, P. (1993), Kraftwerk: Man, Machine and Music, London: SAF.

Cohen, A. (1985), The Symbolic Construction of Community, London: Travistock.

Dallach, C. (2003), 'Die Maschinen spielen uns. Interview mit Ralf Hütter', Der Spiegel, 13 July 2003, pp. 154-155.

Deep Purple (1970), 'Speed King', on Deep Purple in Rock, Harvest SHVL777.

Dome, M. (1987a), 'Helloween: Keeper Pt. 1', Kerrang!, 140, pp. 14-15.

Dome, M. (1987b), 'Helloween. Key to the door', Kerrang!, 156, p. 16.

Dorian, F. (1966), The History of Music in Performance. The Art of Musical Interpretation from the Renaissance to our Day, Toronto: McLeod.

Elflein, D. (2017), 'Restless and wild. Early West German heavy metal', in M. Ahlers and C. Jacke (eds), Perspectives on German Popular Music, London: Routledge, pp. 116-122.

Elias, N. \& Scotson, J. (1994), The Established and the Outsiders, Sage: London.

Everley, D. (2001), 'Germanic Street Preachers', Kerrang!, 847, p. 44-45.

Gehlke, D. E. (2017), Damn the Machine: The Story of Noise Records, Pittsburgh, PA: Deliberation Press.

Glas, S. (1997), 'Accept. True Metal Hearts’, Rock Hard, 12/1997, pp. 60-63.

Grave Digger (2003), Rheingold, Nuclear Blast NB1046-2.

Großer, K. (2001), 'Rammstein. "Wir wollen nur provozieren"', Rock Hard, 4/2001, pp. 2627.

Harry Headbanger (1986), 'Destruction: Eternal Devastation', Kerrang!, 128, p. 18.

Heesch, F. (2014), 'Nordisch - Germanisch - Deutsch? Zur Mythenrezeption im Heavy Metal', in D. Helms and T. Phleps (eds), Typisch Deutsch: (Eigen-)Sichten auf populäre Musik in diesem unserem Land, Bielefeld: Transcript, pp. 127-151.

Helbic, M. (1985), 'Helloween. Power Metal mit Speed in Intelligenz', Metal Hammer, 1985/12, pp. 46-47.

Helloween (1985), Walls of Jericho, Noise N0032.

Helloween (1987), Keeper of the Seven Keys Pt. I, Noise N0061.

Helms, D. and Phleps, T. (2014) (eds), Typisch Deutsch. (Eigen-)Sichten auf populäre Musik in diesem unserem Land, Bielefeld: transcript.

Herbst, Jan-Peter (2019), 'The Formation of the West German Power Metal Scene and the Question of a "Teutonic" Sound', Metal Music Studies, 5:2, pp. 201-223.

Herbst, Jan-Peter (2020), 'German Metal Attack. Power Metal in and from Germany', in O. Seibt, D.-E. Wickström and M. Ringsmut (eds), Made in Germany (Global Popular Music series), London: Routledge (forthcoming).

Herbst, Jan-Peter (2021), 'Culture-specific production and performance characteristics. An interview study with “Teutonic” metal producers', Metal Music Studies (under review).

Hill, R. (1994), "'Overcoming romanticism": on the modernization of twentieth-century performance practice', in B. Gilliam (ed), Music and performance during the Weimar Republic, Cambridge: Cambridge University Press, 37-58. 
Hobsbawm, E. \& Ranger, T. (1992), The Invention of Tradition, Cambridge University Press, Cambridge.

Innes-Parker, C. (2013), Anchoritism in the Middle Ages: Texts and Traditions, Cardiff: University of Wales Press.

Joe, J. (2010), 'Why Wagner and Cinema? Tolkien was wrong', in J. Joe and G. L. Sander (eds), Wagner and Cinema. Bloomington: Indiana University Press, pp. 1-24.

Johansson, M. (2010), 'The Concept of Rhythmic Tolerance. Examining Flexible Grooves in Scandinavian Folk Fiddling', in A. Danielsen (ed), Musical Rhythm in the Age of Digital Reproduction, London: Routledge, pp. 69-83.

Johnson, H. (1990), 'Running Wild', Kerrang!, 277, p. 51.

Kahnke, C. (2013), 'Transnationale Teutonen. Rammstein Representing the Berlin Republic', Journal of Popular Music Studies, 25:2, pp. 185-197.

Kater, M. H. (1988), 'The Jazz Experience in Weimar Germany', German History, 6:2, pp. $145-158$.

Kater, M. H. (1989), 'Forbidden Fruit? Jazz in the Third Reich', The American Historical Review, 94:1, pp. 11-43.

Kerr, A. and Wright, E. (2015), A Dictionary of World History, 3 ed., Oxford: Oxford University Press, p. 655.

Kerrang! (1986), 'Accept Acclaim', Kerrang!, 130, special issue: Legends of Rock.

Kerrang! (1987), ‘Sodom: Expurse of Sodomy', Kerrang!, 141, p. 26.

Kerrang! (1996), 'Rammstein - Herzeleid', Kerrang!, 592, p. 45.

Klüsener, E. (1989), 'Ist Westdeutschland ein rockmusikalisches Entwicklungsland?' Metal Hammer, 1989/3/2, pp. 134-135.

Kohsiek, M. (2018), 'Night Demon. Alles für die Band', Deaf Forever, 24, pp. 37-38.

Kolisch, R. and Mendel, A. (1943), 'Tempo and Character in Beethoven's Music - Part I', The Musical Quarterly, 29:2, pp. 169-187.

Kraftwerk (1974), Autobahn, Philips 6305231.

Kühnemund, G. (2002), 'Running Wild - The Brotherhood', Rock Hard, 3/2002, pp. 93-94.

Kühnemund, G. (2014), 'Accept. Rasend vor Wut - und tiefenentspannt', Deaf Forever, 1/2014, pp. 38-40.

Laibach (2009), 'Volkswagner', http://www.laibach.org/volkswagner; accessed: 12 June 2019.

Lawson, C. and Stowell, R. (1999), The Historical Performance of Music. An Introduction, Cambridge: Cambridge University Press.

Littlejohn, J. T. (2009), 'Kraftwerk: Language, Lucre, and Loss of Identity', Popular Music and Society, 32:5, pp. 635-653

Machine Head (1997), The More Things Change, Roadrunner Records RR8860-5.

Mader, M.; Jeske, O. and Hofmann, A. (1998) (eds), Heavy Metal - Made in Germany, Berlin: I.P. Verlag.

Metal Harry (1985), 'Laaz Rockit', Metal Hammer, 1985/9, pp. 20-21.

Metallica (1983), Kill Em All, Megaforce Records MRIT-069. 
Mühlmann, W.-R. (2002), 'Running Wild. Mensch oder Maschine', Rock Hard, 4/2002, pp. 44-45.

Mühlmann, W.-R. (2018), 'Crime Against Metal. Rock'n'Rolf Kasparek \& Running Wild', Deaf Forever, 23/2018, pp. 38-40.

Myers, B. (2001), 'Industrial Revolution', Kerrang!, 855, p. 40-41.

Mynett, M. (2017), Metal Music Manual, Oxon: Routledge.

Petridis, A. (2003), 'Desperately Seeking Kraftwerk', The Guardian, 25 July 2003, pp. 2.

Poponina, O. (2018), 'Accept's Wolf Hoffmann Never Realized the Band's Classical Influence'; accessed 2 November 2018. http://loudwire.com/accept-wolf-hoffman-never-realized-classical-influence.

Rammstein (2001), 'Links 2, 3, 4', on Mutter, Motor 549639-2.

Reissman, C. S. (2004), 'Rammstein meets Wagner', Stern, 17 February 2004. https://www.stern.de/kultur/musik/crossover-projekt-rammstein-meets-wagner-

3075340.html; Accessed 12 June 2019.

Rinne, C. (1984), 'Hoden an die Wand', Metal Hammer, 1984/1, p. 29.

Ritzel, F. (1998) "'Was ist aus uns geworden? Ein Häufchen Sand am Meer": Emotions of Post-War Germany as Extracted from Examples of Popular Music', Popular Music, 17:3, pp. 293-309.

Running Wild (1987), Under Jolly Roger, Noise N0062.

Running Wild (1991), Blazon Stone, EMI Noise 1C064-7962801.

Running Wild (1994), Black Hand Inn, Electrola 724382916048.

Russell, X. (1986a), ‘A Kold Day In Hell', Kerrang!, 115, pp. 8-10.

Russell, X. (1986b), 'Helloween - Walls of Jericho', Kerrang!, 117, p. 10.

Russell, X. (1986c), 'Rage: Reign of Fear', Kerrang!, 127, p. 16.

Russell, X. (1987a), 'The Seven Keys Of Hell', Kerrang!, 139, p. 30.

Russell, X. (1987b), 'Kreator: Terrible Certainty', Kerrang!, 158, p. 19.

Russell, X. (1991), 'Udo \& Rage concert review', Kerrang!, 342, p. 54.

Schiller, M. (2014), '"Fun Fun Fun on the Autobahn": Kraftwerk Challenging Germanness', Popular Music and Society, 37:5, pp. 618-637.

Schleutermann, M. (2011), 'UDO. Unter der Gürtellinie', Rock Hard, 7/2011, pp. 38-39.

Schulze, K. (1975), Timewind, Brain 1075.

Schürer, P. (2009), 'Teutonischer Tod', Rock Hard, 6/2009, p. 6.

Sheils, L. (1998), 'Accept - All Areas Worldwide', Kerrang!, 680, p. 45

Sindell, J. (2001), 'California Ueber Alles', Kerrang!, 881, pp. 29-36.

Slayer (1983), Show No Mercy, Metal Blade Records MBR1013.

Slayer (2001), God Hates Us All, American Recordings 314586331-2.

Spector, P. (2003), Phil Spector. Out of His Head, London: Omnibus.

Stratmann, H. (2015), 'German Metal Special. Sauerkraut erobert die Welt', Rock Hard, 11/2015, pp. 14-20. 
Stubbs, D. (2010), 'Introduction', in N. Kotsopoulos (ed), Krautrock: Cosmic Rock and its Legacy, London: Black Dog, pp. 4-18.

Thomas, N. (2015), The Development of Technology and its Influence on Recorded Heavy Metal Music 1969-2015, PhD thesis, University of Hull.

Thornton, M. (2018), 'The History of Pro Tools - 2000 to 2007', Pro Tools Expert, https://www.pro-tools-expert.com/home-page/2018/2/26/the-history-of-pro-tools-2000to-2007; accessed 14 June 2019.

Van der Kirkhoff, W. (1993), 'Accept - Objection Overruled', Kerrang!, 429, p. 21.

Wagner, R. (1869), On Conducting, http://www.gutenberg.org/cache/epub/4523/pg4523-images.html; accessed 15 June 2019.

Wahrig, G. (1984), Brockhaus-Wahrig. Deutsches Wörterbuch, Wiesbaden: Brockhaus.

Warrior, T. G. (2016), 'European Metal', Deaf Forever, 12/2016, pp. 25-26.

Waterman, R. (1948), '"Hot”'Rhythm in Negro Music', Journal of the American Musicological Society, 39:2, pp. 24-37.

Watts, C. (1989), 'M.E.A.N. M.A.N. (U.D.O.)', Kerrang!, 1989/243: 38-39.

Watts, C. (1992), 'Sargant Fury - Still Want More', Kerrang!, 383, p. 21.

Weichert, M. (2015), 'German Metal? German Metal!', Rock Hard, 11/2015, p. 14.

Weinstein, D. (2011), 'The globalization of Metal', in J. Wallach, H. M. Berger and P. D. Greene (eds), Metal rules the globe. Heavy metal around the world, Durham: Duke University Press, pp. 34-59.

Wicke, P. (1997), 'Populäre Musik im faschistischen Deutschland', PopScriptum, https://www2.hu-berlin.de/fpm/textpool/texte/wicke populaere-musik-im-faschistischendeutschland.htm\#a9; accessed: 13 June 2019.

Williams, D. (2015), 'Tracking timbral changes in metal productions from 1990 to 2013', Metal Music Studies, 1:1, pp. 39-68.

Williams, R. V. (1932), 'Weber, Der Freischütz Overture', in D. Manning (2008) (ed), Vaughan Williams on Music, Oxford: Oxford University Press, pp. 415-416.

Zagorski-Thomas, S. (2010), 'Real and Unreal Performances. The Interaction of Recording Technology and Rock Drum Kit Performance', in A. Danielsen (ed), Musical Rhythm in the Age of Digital Reproduction, London: Routledge, pp. 195-229. 